\title{
Exploring in-Service Teachers' Self-Efficacy in the Kindergarten Classrooms in Ghana
}

\author{
Philip Boateng \\ Department of Interdisciplinary Studies, University of Education, Winneba, Ghana, \\ pboateng@uew.edu.gh

\section{Frank Owusu Sekyere} \\ Department of Interdisciplinary Studies, University of Education, Winneba, Ghana, \\ fosekyere@uew.edu.gh
}

The study explored in-service teachers' efficacy beliefs in pupil engagement. The sample size was 299 kindergarten teachers selected from both public and private kindergarten schools in the Kumasi metropolis of Ghana. The study adopted and used pupil engagement subscale of the Ohio State Teacher Efficacy Scale (OSTES) developed by Tschannen-Moran and Woolf Hoy (2001) as survey instrument. Results of the study revealed that kindergarten teachers in the Kumasi metropolis of Ghana have high efficacy beliefs in pupils' engagement. No statistically significant difference was found in the efficacy beliefs in pupil engagement of trained and untrained kindergarten teachers. The results also show that efficacy beliefs in pupil engagement among public and private kindergarten school teachers did not differ significantly. It is argued that the training background of the teachers (i.e. whether they were trained or untrained) and their institutional placement (i.e. whether they taught in a public or private school) are not essential influential factors in teachers' efficacy beliefs in pupil engagement. Implications of the findings for research and practice are discussed.

Keywords: early childhood teacher education, kindergarten teachers, pupil engagement, self-efficacy beliefs, teacher education

\section{INTRODUCTION}

In 2007, Ghana reformed its educational system in order to promote the development of well-balanced individuals with the requisite knowledge, skills, values, aptitudes and attitudes to become functional and productive citizens (MOEYS, 2004). Core to this reform was the re-definition of Free Compulsory Universal Basic Education (fCUBE). The new definition far exceeds the standards required by the various international conventions on people's right to which Ghana has subscribed such as the United Nations Sustainable Development Goals. It also demonstrates Ghana's commitment to the

Citation: Boateng, P,. \& Sekyere, F. O. (2018). Exploring in-Service Teachers' Self-Efficacy in the Kindergarten Classrooms in Ghana. International Journal of Instruction, 11(1), 239-254. https://doi.org/10.12973/iji.2018.11117a 
promotion of the physical, mental and social well-being of the Ghanaian child as enshrined in the 1992 Constitution of Ghana and the Children's Act 1998 (Act 560). The New Free Compulsory Universal Basic Education comprises 2 years of kindergarten, 6 years of primary education and 3 years of junior high school. This is meant to cater for all of Ghana's children from age 4 to age 15 . Kindergarten, now part of the Free Compulsory Universal Basic Education (fCUBE) is part of early childhood education. Early Childhood Care and Education (ECCE) is acknowledged worldwide as critical to the development of individuals and society as a whole. It has also been recognized as the key to preparing children for a successful primary school experience by improving upon the internal efficiency, reducing repetitions and drop-out rates in the education system (UNICEF, 2007). Education For All [EFA], Global Monitoring Report, (2007) also confirms that children's success in life begins in early childhood years, and investment in ECCE has a direct and positive impact on primary school enrolments, retention and completion.

The aim of integrating kindergarten education into the basic school structure in Ghana was to ensure that all primary school children have a basic education rooted in good kindergarten training (MOEYS, 2004). The incorporation of kindergarten education into the Free Compulsory Universal Basic Education seeks to achieve about five objectives. The objectives are to (1) pre-dispose children to conditions of formal schooling in order to accelerate the learning process during formal education; (2) strengthen primary education through the provision of pre-school education; (3) inculcate in children the desire of learning; (4) introduce children to basic hygiene and sanitation for healthy living; and (5) minimize gender barriers which seem to affect girls even before they enter primary school (MoE, 2002).

To achieve these objectives implies that teachers need to employ developmentally appropriate measures to engage pupils in the academic and social aspects of kindergarten school life. Researchers, educators and policymakers have placed much emphasis on pupil engagement as a key to addressing problems of low achievement, high levels of pupil boredom, alienation and high dropout rates (Fredricks, Blumenfeld $\&$ Paris, 2004). The importance of engaging all students or pupils in their education also continues to resonate strongly with families, students, educators and researchers because too many students are bored, unmotivated and uninvolved; they are disengaged from the academic and social aspects of school life (Appleton, Christenson, \& Furlong, 2008). Research has confirmed that students who are engaged in their education consider school as valuable experience and want to participate in school activities. They are also more likely to demonstrate high academic achievement (Wang \& Holcome, 2010) and are less likely to drop out of school (Finn \& Rock, 1997).

Over the years successive governments in Ghana have made frantic efforts and commitments toward promoting school engagement with the view to enhancing students' learning and increasing retention. But many of these efforts seem to have targeted the junior high schools under the rubric of improving performance, preventing drop- out and promoting retention. The focus on the junior high schools is as a result of the high-stake of the Basic Education Certificate Examination (BECE) conducted at this 
level to determine learning outcomes and the effectiveness of the school curriculum. However, Ghana's BECE pass rate has remained at an average of $60 \%$ in the past decade whereas proficiency and numeracy levels in primary schools continue to linger between $30 \%$ and $40 \%$ during the same period (Ministry of Education [MoE], 2012). The low numeracy, literacy and BECE performance levels have often been hurriedly attributed to immediate and intermediate factors such as low quality of teachers, the lack of quality school infrastructure and classroom environment, the lack of adequate pupils' preparation for BECE examinations and low quality of supervision in basic schools (Asare, 2012).

One major cause of low literacy, numeracy and BECE performances in Ghana that stakeholders normally overlook is the quality of and access to kindergarten education. Kindergarten education forms the bedrock of children's learning (UNICEF, 2007). Upon careful observation of kindergarten schools and their enormous problems, one can say that successive governments have demonstrated a little commitment to improving kindergarten education in the country. As a result, many children leave kindergarten school without acquiring most of the basic skills partly because these children are of different ages and abilities mixed together in single classrooms without proper adaptation of teaching methods to improve learning and to induce school engagement (Little, 2008). Again, their schooling experience consists mostly of limited learning opportunities in overcrowded classrooms with insufficient learning materials and underqualified teachers (Alexander, 2008). For example, during the 2011/12 academic year, there was a total of 31,691 preschool teachers in the country. The majority of the preschool teachers representing 55.2\% were untrained (MoE, 2016).

\section{Statement of the Problem}

Implementing the kindergarten curriculum to achieve its stated objectives requires that teachers need to possess adequate knowledge and skills to effectively and efficiently engage pupils in the academic and social aspects of school life. That means they need to ensure that all children registered and enrolled in their schools attend, progress, learn and participate in educationally purposeful activities. However, many kindergarten schools are staffed with untrained and unqualified teachers (Asare, 2012; Cobbold \& Boateng, 2016) who do not possess the requisite knowledge and skills to help these young children develop the joy of learning. They are, therefore, likely to have doubt about their abilities and competences in shaping kindergarten pupils' everyday experiences in the school. There is, therefore, the need to examine kindergarten teachers' efficacy of engaging pupils in a wide range of educational activities that will lead to high-quality learning in kindergarten classrooms and subsequently impact directly and positively on primary school enrolments, retention, and completion.

Many studies on teacher efficacy have focused on pre-service teachers (Woolfolk \& Hoy, 2001), novice teachers (Ozder, 2011) as well as elementary and secondary school teachers. Not many studies have focussed on kindergarten teachers' efficacy beliefs about their pupil engagement. A few available studies in Ghana focused on kindergarten teachers' efficacy for instructional practices (Cobbold \& Boateng, 2015) and efficacy 
for classroom management practices (Cobbold \& Boateng, 2016). The current study is an attempt to fill this void left by previous studies.

\section{Research Question and Hypotheses}

The following research questions were formulated to provide direction for the study:

1. What are kindergarten teachers' efficacy beliefs about their pupils' engagement in the classroom?

2. How does the training background of teachers influence their efficacy beliefs in pupil engagement?

3. How does the type of school (public or private) teachers teach influence their efficacy beliefs in pupil engagement

Research questions 2 and 3 were turned into the following hypotheses.

Hypothesis 1: There will be no statistically significant difference in the efficacy beliefs of public and private kindergarten teachers with regards to their pupils' engagement.

Hypothesis 2: There will be no statistically significant difference in the efficacy beliefs of trained and untrained kindergarten teachers with regards to their pupils' engagement.

\section{Conceptualising Pupils' Engagement}

Over the years, different researchers have attempted to conceptualise pupil engagement for the understanding of both practitioners and researchers. Their views differ depending on their general orientation and the message they want to put across. Student engagement is a term used to describe an individual's interest and enthusiasm for school, which impacts their academic performance and behaviour (Gallup, 2013). Student engagement has been defined as participation in educationally effective practices, both inside and outside the classroom, which leads to a range of measurable outcomes (Kuh, Kinzie, Buckley, Bridges \& Hayek, 2007).

According to Stovall (2003), engagement is defined as a combination of students' time on task and their willingness to participate in activities. Krause and Coates (2008) noted that engagement is the quality of effort students themselves devote to educationally purposeful activities that contribute directly to desired outcomes. Again, Chen, Gonyea and Kuh (2008) maintain that engagement is the degree to which learners are engaged with their educational activities and that engagement is positively linked to a host of desired outcomes, including high grades, student satisfaction, and perseverance. Mark (2000) defined engagement as a psychological process, specifically, the attention, interest, investment, and effort students expend in the work of learning. Olson and Peterson (2015) defined student engagement as the degree of attention, curiosity, interest, optimism, and passion that students show when they are learning or being taught, which extends to the level of motivation they have to learn and progress in their education. Student engagement mostly involves positive student behaviours, such as attendance, paying attention, and participation in class, as well as the psychological experience of identifying with school and feeling that one is cared for, respected, and part of the school environment (Anderson, Christenson, Sinclair, \& Lehr, 2004). Even 
though, different authors have given various interpretation of the concept of student engagement, they all seem to emphasise how educators and or the school engage learners in educationally valuable learning experiences in order to promote active learning.

The definition of school engagement is complex, and there has been some disagreement with regard to the number of theoretical dimensions. Some scholars argue for two dimensions (i.e., behavioural and emotional (Finn \& Voelkl, 1993; Skinner \& Belmont, 1993), and other scholars argue for three dimensions (i.e., behavioral, emotional, and cognitive (Fredricks, Blumenfeld, \& Paris, 2004). Archambault and colleagues (2009) identify three distinct categories of student engagement: behavioural engagement, affective engagement, and cognitive engagement. The first type of student engagementbehavioural engagement includes a student's compliance with rules and involvement in the classroom and with extracurricular activities. The second type of student engagement, affective engagement, includes the experience, feelings, attitudes, and perceptions a student has towards school, specifically the student's sense of belonging, interest, willingness to learn, and a general sense of liking school. The third type of engagement, cognitive engagement, refers to the cognitive functions involved in a student's learning process.

According to Skinner and Pitzer (2012), student engagement is critical for three reasons. First, it is a necessary condition for students to learn only if students participate in academic activities with both "hands-on" and "heads-on". When this happens, the time that students spend in classroom will result in the acquisition of knowledge and skills. No matter how many extracurricular activities students undertake or how attached they are to school, they will not learn or achieve anything unless they are constructively engaged in the academic work of the classroom.

Second, engagement shapes students' everyday experiences in school, both psychologically and socially. High-quality engagement and its resultant learning and scholastic success lead students to feel more academically competent and connected, and elicit more positive support from teachers. Disengaged students tend to perform poorly in school and feel so marginalised, resentful and ineffective. Teachers respond to such students with less support and more coercion, and disaffected students are more likely to join disengaged peer groups and become friends with other disaffected students. Hence, students' classroom engagement plays an important role in the quality of their daily experiences while they are attending school.

Third, engagement is a critical contributor to students' academic development. Engagement is a part of the process of everyday academic resilience and an energetic resource that helps students cope more adaptively with daily stressors, challenges and setbacks in the school. Engagement can be seen as a key player in the development of academic asset that takes place across the school year and over the arc of a student's entire educational career (Skinner \& Pitzer, 2012).

Student engagement is active learning. According to Kidwell (2010), if students are not engaged in the learning process, all of the testing, data analysis, teacher meetings, and 
instructional minutes in the world will not motivate students to learn. Another important benefit of student engagement is that students who are engaged in school are less likely to fall victim to potential adolescent troubles (Olson \& Peterson, 2015). O'Farrell and Morrison (2003) have suggested that student engagement protects against behaviours that are not a part of the school environment, such as substance abuse, risky sexual behaviours, and delinquency. Research has shown that students' sense of belonging at school, which can come as a result of facilitating student engagement in school activities, gatherings, and access to adults and other students, influences students' psychological and academic results in a positive way (Kortering \& Braziel, 2008).

\section{Research on Teacher Efficacy for Student Engagement}

Ladd, Birch and Buhs (1999) note that kindergarteners who are more behaviourally engaged in the classroom tend to develop closer relationships with their teachers over time than those who are less engaged. In the same vein, two observational studies, one of middle schoolers (Altermatt, Jovanovic, \& Perry, 1998) and the other junior high schoolers (Fiedler, 1975) reveal that students who show more participation in class elicit greater teacher responsiveness.

According to Olson \& Peterson (2015), the nature of the interactions teachers have with their students can shape student engagement in the classroom in at least two ways: First, it promotes students' intrinsic motivation by offering challenging and fun learning activities that encourages students to discover and follow their own interests and set realistic goals to achieve. It also provides clear instruction and feedback about how students can reach their goals. Second, it creates classroom contexts that support the development of more self-determined reasons for accomplishing the parts of learning that are not intrinsically fun. Students are more likely to internalize autonomous reasons for completing extrinsically motivated tasks in school when they learn from teachers who display the three features of motivational support. The features of motivational support displayed by teachers include: (1) fostering a caring relationships (warmth and involvement), (2) providing challenging learning activities with high expectations and clear feedback (optimal structure), and (3) explaining the relevance and importance of activities and rules while soliciting input from students and respecting their opinions (autonomy support) (Connell \& Wellborn, 1991; Deci \& Ryan, 2000).

Teachers can facilitate students' engagement and constructive coping directly through their own actions and modelling in the classroom. Teachers' enthusiasm and excitement about a subject can be contagious (Patrick, Hisley, Kempler, \& College, 2000). Teachers' hard work and careful thought can communicate the importance and value of knowledge and skills. Student engagement is strongly related to teachers' self-efficacy, Patrick et al. (2000) conclude that track and age effects on student efficacy are closely tied to track and age effects on student engagement. In other words, the possibility exists that teachers found low-track students and younger students to be difficult to engage, thereby feeling less able to carry out the tasks needed to affect performance for these students (Raudenbush, Brown \& Cheong, 1992). 
To sum it up, teachers' sense of efficacy for student engagement reflects a person's confidence that they can help students become and remain involved, invested, or motivated for learning (Tschannen-Moran \& Woolfolk-Hoy, 2001).

\section{METHOD}

The study explored in-service teachers' efficacy beliefs in pupil engagement. The study used cross-sectional descriptive survey design since the researchers sought to present a single time description of kindergarten teachers' efficacy beliefs regarding their pupil engagement through posing questions to a carefully selected sample (Babbie, 1990). Cross-sectional design was also deemed appropriate for the study in three ways. First, it enabled the researchers to obtain information from large samples of the population. Second, it was well suited for gathering demographic data that describe the composition of the sample (McIntyre, 1999). Finally, it required minimal investment to develop and administer, and are relatively easy for making generalisations (Bell, 1996).

\section{Population and Sample Selection}

The population for the study was all kindergarten teachers (trained or untrained) who were working in the Kumasi Metropolis of Ghana during the 2013/2014 academic year. A list obtained from the Metropolitan Education Directorate indicated that there were 972 kindergarten schools with an estimated number of 1156 teachers in the metropolis.

A multi-phase sampling technique was employed to draw a sample of 350 teachers. Cohen, Manion and Morrison (2007) note that the purpose and population of sampling change at each phase of the sampling process in multi-phase sampling. In this study, the first stage of sampling consisted of stratifying the schools into public ( 202 schools) and private (770 schools) and purposively sampled schools which had operated for five years or more, and were recognized by the Ghana Education Service (GES) and the Social Welfare Department (SWD) in the metropolis. The criterion of five years was based on the idea by educational evaluators notably; Fullan (2007) who is of the opinion that 5 years is sufficiently enough period to assess any aspect of a school's instructional program. Recognition of the schools by the GES and SWD also ensured that those schools operated under nationally accepted conditions in terms of physical infrastructure and instructional resources, among other criteria. This method yielded 75 public schools and 100 private schools that were used for the study. In the second phase of sampling, all kindergarten 1 and 2 teachers from the public and private schools that had been sampled during the first stage were selected for the study. The total number of teachers was 350 .

The pupil engagement subscale of the Ohio State Teacher Efficacy Scale (OSTES) developed by Tschannen-Moran and Woolf Hoy (2001) was adopted and used as survey instrument for the study. The survey instrument consisted of two parts. The first part included 6 items measuring teachers' demographic characteristics such as age, educational background, the length of teaching experience, gender, professional status as well as the type of school they were teaching. The second part of the instrument had 8 items on a 6-point Likert scale (1-strongly disagree to 6- strongly agree) measuring teachers' efficacy beliefs for pupil engagement. 
Though the reliability of the OSTES had been established, the instrument was pretested to re-establish its reliability in the Ghanaian context. The pretesting was conducted with a tryout sample of 45 kindergarten teachers (26 from public schools and 19 from private schools) in the Atwima Nwabiagya District. The participants were asked to respond to the items and also make comments related to the statements for clarity.

The Alpha reliability coefficient was calculated to measure the internal consistency of the questionnaire items. The reliability coefficient of the pupil engagement subscale was found to be .78. This means the internal consistency of the items was good (George \& Mallery (2003) or high (Gliem \& Gliem, 2003) and, therefore, the instrument as a whole was acceptable.

\section{Data Collection Procedure}

The questionnaires were administered personally to the respondents in their respective schools from February to April, 2014. Entry to each school was obtained by presenting an approval letter from the Metropolitan Director of Education to the head teachers who gave permission to engage the kindergarten teachers. In each school, the purpose of the study was explained to the teachers and they were given an assurance of anonymity and confidentiality. All ethical procedures were fully fulfilled.

All kindergarten 1 and 2 teachers sampled from the public and private schools were asked to fill out a questionnaire. In all, 350 questionnaires were administered and a total of 299 , representing $85.43 \%$ was properly completed and returned.

\section{Data Analysis}

The analysis employed both descriptive and inferential statistical tools. The resultant data from the descriptive analysis were organised into tables of frequency and simple percentages. A t-test for independent samples was conducted to investigate the possible differences in teachers' efficacy beliefs for pupil engagement in respect of the type of school and professional status. The 0.05 alpha level was used as a criterion of statistical significance for all the statistical procedures performed. The results of the data analysis are presented in the next section.

\section{FINDINGS}

Two hundred and ninety-nine (299) teachers participated in the study. The age of the respondents ranged from 20 to 61 . Men constituted $18.7 \%$ whereas $81.3 \%$ was women. About $57.2 \%$ of the respondents was teaching in public schools compared to $42.8 \%$ who worked in private kindergarten schools. The majority $(64.2 \%)$ of the kindergarten teachers had low academic and professional background whereas $35.8 \%$ had the academic and professional background required to teach at the basic school in Ghana.

\section{Kindergarten Teachers Self-efficacy Beliefs about Pupils' Engagement}

Eight items on a six-point Likert-type agreement scale were used to measure respondents' efficacy beliefs in pupil engagement. Teachers' responses were coded as follows: $1=$ Strongly Disagree (SD), 2=Moderately Disagree (MD), $3=$ Disagree (D), 4= 
Agree (A), 5= Moderately Agree (MA) and 6= Strongly Agree (SA). In the interpretation of the scores, frequencies, mean and standard deviation were used, and the means were interpreted as follows: 1.00-3.49 indicate low efficacy and 3.50-6.00 indicate high efficacy. Table 1 presents the results.

Table 1

Respondents' efficacy beliefs for pupil engagement

\begin{tabular}{|c|c|c|c|c|c|c|c|c|c|}
\hline Efficacy for Pupil Engagement & SD & MD & $\mathrm{D}$ & A & MA & SA & Total & Mean & STD \\
\hline $\begin{array}{l}\text { I am able to motivate pupils who } \\
\text { show low interest in schoolwork }\end{array}$ & $\begin{array}{l}3 \\
1 \%\end{array}$ & $\begin{array}{l}7 \\
2.4 \%\end{array}$ & $\begin{array}{l}51 \\
17.2 \%\end{array}$ & $\begin{array}{l}71 \\
24 \%\end{array}$ & $\begin{array}{l}73 \\
24.7 \%\end{array}$ & $\begin{array}{l}91 \\
30.1 \%\end{array}$ & 296 & 4.61 & 1.211 \\
\hline $\begin{array}{l}\text { I believe I can do much to get } \\
\text { pupils to believe that they can do } \\
\text { well in schoolwork }\end{array}$ & $\begin{array}{l}3 \\
1 \%\end{array}$ & $\begin{array}{l}17 \\
5.8 \%\end{array}$ & $\begin{array}{l}39 \\
13.3 \%\end{array}$ & $\begin{array}{l}84 \\
28.6 \%\end{array}$ & $\begin{array}{l}59 \\
20.1 \%\end{array}$ & $\begin{array}{l}92 \\
31.3 \%\end{array}$ & 294 & 4.55 & 1.270 \\
\hline $\begin{array}{l}\text { I am able to help pupils with lower } \\
\text { abilities to understand my lessons }\end{array}$ & $\begin{array}{l}1 \\
0.3 \% \\
\end{array}$ & $\begin{array}{l}12 \\
4.1 \% \\
\end{array}$ & $\begin{array}{ll}44 \\
14.9 \% \\
\end{array}$ & $\begin{array}{l}82 \\
27.7 \% \\
\end{array}$ & $\begin{array}{l}82 \\
27.7 \% \\
\end{array}$ & $\begin{array}{l}75 \\
25.3 \% \\
\end{array}$ & 296 & 4.54 & 1.158 \\
\hline $\begin{array}{l}\text { I am able to help my pupils to value } \\
\text { learning }\end{array}$ & $\begin{array}{l}2 \\
0.7 \%\end{array}$ & $\begin{array}{l}9 \\
3.1 \%\end{array}$ & $\begin{array}{l}47 \\
15.9 \%\end{array}$ & $\begin{array}{l}95 \\
32.2 \%\end{array}$ & $\begin{array}{l}56 \\
19 \%\end{array}$ & $\begin{array}{l}86 \\
29.2 \%\end{array}$ & 295 & 4.53 & 1.192 \\
\hline $\begin{array}{l}\text { I believe I can do much to foster } \\
\text { pupils creativity in my classroom }\end{array}$ & $\begin{array}{l}4 \\
1.4 \%\end{array}$ & $\begin{array}{l}14 \\
4.7 \%\end{array}$ & $\begin{array}{ll}50 \\
16.9 \% \\
\end{array}$ & $\begin{array}{l}75 \\
25.4 \%\end{array}$ & $\begin{array}{l}76 \\
25.8 \%\end{array}$ & $\begin{array}{l}76 \\
25.8 \%\end{array}$ & 295 & 4.47 & 1.247 \\
\hline $\begin{array}{l}\text { I can take adequate measures to } \\
\text { improve the understanding of a } \\
\text { pupil who is falling }\end{array}$ & $\begin{array}{l}3 \\
1 \%\end{array}$ & $\begin{array}{l}13 \\
4.4 \%\end{array}$ & $\begin{array}{l}56 \\
19 \%\end{array}$ & $\begin{array}{l}86 \\
29.2 \%\end{array}$ & $\begin{array}{l}69 \\
23.4 \%\end{array}$ & $\begin{array}{l}68 \\
23.1 \%\end{array}$ & 295 & 4.39 & 1.212 \\
\hline $\begin{array}{l}\text { I am able to assist families in } \\
\text { helping their children to do well in } \\
\text { school }\end{array}$ & $\begin{array}{l}5 \\
1.7 \%\end{array}$ & $\begin{array}{l}14 \\
4.7 \%\end{array}$ & $\begin{array}{l}54 \\
18.2 \%\end{array}$ & $\begin{array}{l}86 \\
29.1 \%\end{array}$ & $\begin{array}{l}74 \\
25 \%\end{array}$ & $\begin{array}{l}63 \\
21.3 \%\end{array}$ & 296 & 4.35 & 1.228 \\
\hline $\begin{array}{l}\text { I am able to do much to help my } \\
\text { pupils think critically }\end{array}$ & $\begin{array}{l}6 \\
2 \% \\
\end{array}$ & $\begin{array}{l}18 \\
6.1 \% \\
\end{array}$ & $\begin{array}{l}53 \\
17.8 \% \\
\end{array}$ & $\begin{array}{l}84 \\
28.3 \% \\
\end{array}$ & $\begin{array}{ll}77 \\
25.9 \% \\
\end{array}$ & $\begin{array}{ll}59 \\
19.9 \% \\
\end{array}$ & 297 & 4.30 & 1.255 \\
\hline Overall Mean Score & & & & & & & & 4.47 & 1.222 \\
\hline
\end{tabular}

As shown in Table 4.1, the kindergarten teachers in the study area reported high efficacy for all the eight pupil engagement practices listed with the overall mean score of 4.39 $(\mathrm{SD}=1.243)$. Interestingly they rated their ability to motivate pupils who show low interest in school work higher $(\mathrm{M}=4.61, \mathrm{SD}=1.211)$ than they are able to help pupils think critically $(\mathrm{M}=4.30, \mathrm{SD}=1.255)$. Teachers' rating of their ability to promote critical thinking lower than motivating pupils is not surprising because critical thinking appears to be the missing link in our education system which mostly focuses on mastery of the content knowledge.

\section{Hypothesis Testing}

This study presumed that the training background of kindergarten teachers and the type of school where they teach could be significant factors in estimating their efficacy in pupil engagement. This assumption informed the two research hypotheses formulated for the study. Both hypotheses were tested using the independent samples t-test statistical technique at a p-value of 0.05 .

\section{Type of School and Efficacy for Pupil Engagement}

Hypothesis 1: there will be no statistically significant difference in the efficacy beliefs of public and private kindergarten teachers with regards to their pupils' engagement. 
The results of the statistical test for this hypothesis are presented in Table 2

Table 2

Independent Sample T-test on Efficacy Beliefs in Pupil Engagement of Public and Private Kindergarten Teachers

\begin{tabular}{lcccc}
\hline Efficacy for Students Engagement & DF & MD & t & P-value \\
\hline $\begin{array}{l}\text { I believe I can do much to get pupils to believe that } \\
\text { they can do well in schoolwork }\end{array}$ & 292 & .034 & .227 & .821 \\
\hline I am able to help my pupils to value learning & 293 & -.209 & -1.490 & .137 \\
\hline $\begin{array}{l}\text { I am able to motivate pupils who show low interest in } \\
\text { schoolwork }\end{array}$ & 294 & -.172 & -1.210 & .227 \\
\hline $\begin{array}{l}\text { I am able to assist families in helping their children to } \\
\text { do well in school }\end{array}$ & 294 & -.201 & -1.391 & .165 \\
\hline $\begin{array}{l}\text { I can take adequate measures to improve the } \\
\text { understanding of a pupil who is failing }\end{array}$ & 293 & .018 & .127 & .899 \\
\hline $\begin{array}{l}\text { I am able to do much to help my pupils think critically } \\
\text { I believe I can do much to foster pupils creativity in my } \\
\text { classroom }\end{array}$ & 295 & -.018 &.- .125 & .901 \\
\hline $\begin{array}{l}\text { I am able to help pupils with lower abilities to } \\
\text { understand my lessons }\end{array}$ & 294 & -.076 & -.516 & .606 \\
\hline
\end{tabular}

*p-value significant at .05 (2-tailed)

The results of independent sample t-test show that efficacy beliefs in student engagement of public and private kindergarten school teachers do not differ significantly. There was no statistically significant difference ( $p>.05$ for all cases), to show that efficacy beliefs for pupil engagement practices between public and private kindergarten teachers differ. The null hypothesis is therefore upheld.

Training Background of Kindergarten Teachers and Pupil Engagement

Hypothesis 2: there will be no statistically significant difference in the efficacy beliefs of trained and untrained kindergarten teachers with regards to their pupils' engagement.

The results of the statistical test for hypothesis 2 are presented in Table 3. 
Table 3

Independent Sample t-test on Efficacy Beliefs in pupil Engagement of Trained and Untrained Kindergarten Teachers

\begin{tabular}{|c|c|c|c|c|}
\hline Efficacy for Students Engagement & DF & MD & $\mathrm{t}$ & P-value \\
\hline $\begin{array}{l}\text { I believe I can do much to get pupils to believe that } \\
\text { they can do well in schoolwork }\end{array}$ & 292 & .179 & 1.157 & .248 \\
\hline I am able to help my pupils to value learning & 293 & .105 & .726 & .468 \\
\hline $\begin{array}{l}\text { I am able to motivate pupils who show low interest in } \\
\text { schoolwork }\end{array}$ & 294 & .199 & 1.358 & .175 \\
\hline $\begin{array}{l}\text { I am able to assist families in helping their children to } \\
\text { do well in school }\end{array}$ & 294 & .237 & 1.595 & .112 \\
\hline $\begin{array}{l}\text { I can take adequate measures to improve the } \\
\text { understanding of a pupil who is failing }\end{array}$ & 293 & .169 & 1.147 & .252 \\
\hline I am able to do much to help my pupils think critically & 295 & .165 & 1.089 & 277 \\
\hline $\begin{array}{l}\text { I believe I can do much to foster pupils creativity in } \\
\text { my classroom }\end{array}$ & 293 & .175 & 1.160 & .247 \\
\hline $\begin{array}{l}\text { I am able to help pupils with lower abilities to } \\
\text { understand my lessons }\end{array}$ & 294 & -.083 & -.592 & .555 \\
\hline
\end{tabular}

The results of Independent Sample t-test show that efficacy beliefs in pupil engagement among trained and untrained kindergarten teachers do not differ. The null hypothesis could, therefore, not be rejected because there was statistical evidence ( $p>.05$ for all cases), meaning that student engagement practices among trained and untrained kindergarten teachers do not differ significantly.

\section{DISCUSSION}

The results of independent sample t-test on efficacy beliefs in student engagement among public and private kindergarten teachers show that student engagement practices among public and private kindergarten teachers did not differ significantly $\left(t_{294}=-\right.$ $.0650 ; \mathrm{p}=.505)$. Although, the researchers have not sighted any extant study in pupil engagement among public and private kindergarten teachers in Ghana, the finding of the study is not surprising given the expectations of parents and school administrators from the public and private schools in Ghana. In private preschools, parents and school administrators appear to expect more from preschool teachers related to children's academic success, so the teachers show more effort in engaging pupils to satisfy the expectation of parents and school heads. Again, school heads in private schools tend to monitor preschool teachers periodically and give scores based on their performance (Edern, 2010) and that they might be more likely to show their positive experience in engaging pupils in their attempt to implement the kindergarten curriculum in order to retain their jobs.

Another reason which contributes to the non significant difference is that teachers in the public kindergarten schools seem to have difficulty with adequate supply of basic teaching materials like textbooks and other play materials. These situations may tend to 
affect the way they engage pupils in the classroom to promote and enhance learning. Teachers cannot effectively implement the curriculum unless they are given tools of the trade which are facilities and materials. A World Bank Report (1997) identifies the scarcity of learning materials in the classroom as one of the most serious impediments to educational effectiveness. Beaty (2000) also underscores the importance of teaching and learning resources in an early childhood classroom. She notes that the physical arrangement of materials determines what will happen; it conveys to the children what they may or may not do and what is expected of them.

Young children require a variety of materials to facilitate their learning. The attention span of children is very short; as such, they get bored very fast and the only way to sustain their interest and curiosity in learning is by providing a variety of materials. This, however, is not the case in most kindergarten schools in the Kumasi metropolis. Therefore, inadequate teaching resources at the public kindergarten schools have a propensity to decrease teachers' efficacy beliefs in pupils' engagement since research indicates that teaching resources significantly enhance teachers' efficacy for student engagement (Gur, Cakiroglu \& Capa Aydin, 2012).

The findings showed no statistically significant difference ( $p>.05$ for all practices) in the pupil engagement among trained and untrained kindergarten teachers. In general, there are few studies conducted in Ghana and elsewhere to explore the efficacy beliefs for pupils' engagement among trained and untrained teachers. A study by Tschannen-Moran and Hoy (2002) to explore the influences of resources and support on teachers' efficacy beliefs found no significant difference among novice and experienced teachers with respect to their sense of efficacy for student engagement. The researchers believe that no significant difference found among trained and untrained kindergarten teachers' efficacy for pupil engagement could be partly due to the fact that teaching and nurturing young children is often difficult and uniquely complex and may present a challenge to early childhood educators (Pianta, 2007). Children enter early childhood programmes with various needs and at different developmental levels and therefore teaching in early education programmes that target children who live below the poverty line can be even more challenging, especially if the class includes children who need extra support (Pianta, 2007). Again, it could be due to social desirability bias. In the Ghanaian context, self-image may seem socially conferred or denied and reporting about one's abilities regardless of professional training may be influenced by the need for acceptance or social approval. The researchers believe that perhaps respondents in the study, more especially the untrained teachers may have chosen responses they believed are more socially desirable or acceptable rather than choosing responses that were true reflective of their thoughts or feelings.

\section{CONCLUSION}

Based on the findings of the study, the following conclusions were drawn:

Kindergarten teachers in the Kumasi metropolis of Ghana have a high sense of efficacy for pupil engagement. This implies that they are highly confident in their ability to help pupils become and remain involved, invested, or motivated for learning. 
The training background and the types of school kindergarten teachers teach (whether public or private) did not seem to influence their efficacy for pupil engagement. This is to suggest that kindergarten teachers in the Kumasi metropolis have confidence in their ability to engage pupils in educationally purpose activities in the classroom regardless of their professional training and the type of school they teach.

The findings of the study have implications for research and practice. First, early childhood teacher education programmes in Ghana should focus more on equipping the teachers on how to engage pupils as individuals or group in a range of educationally purposeful activities to help them become and remain involved, invested, or motivated for learning. Second, further research on the topic of teacher self-efficacy in pupil engagement should be conducted with a larger sample drawn from a widely distributed population to determine possible factors that influence how they engage pupils in the kindergarten classroom. Finally, a noticeable limitation of this study was that it relied only on teachers' self-reported data. Self-reported may not always provide an accurate snapshot of actual beliefs (Gravetter \& Forzano, 2009). Further studies on efficacy for pupil engagement that support kindergarten teachers' self-reported data with direct observation and interviewing participants may be preferred to ascertain their actual sense of efficacy.

\section{REFERENCES}

Alexander, R. (2008). 'Education for All, the Quality Imperative and the Problem of Pedagogy.' CREATE Pathways to Access No 20. Consortium for Research on Educational Access, Transitions and Equity: University of Sussex.

Asare, K. (2010). Improving kindergarten education in Ghana: Perspectives from th 2012 civil society education manifesto. Retrieved from www.areghana.org.

Babbie, E. R. (1990). Survey research methods. Belmont,CA: Wadsworth Publishing.

Beaty, J. J. (2000). Skills for pre-school teachers $\left(6^{\text {th }}\right.$ ed.). New Jersey: Prentice Hall.

Bell, S. (1996). Learning with information systems: Learning cycles in information systems development. New York: Routledge.

EFA (2006). Education For All Global Monitoring Report. UNESCO. Retrieved from www.efareport.unesco.org.

Erden, E. (2010). Problems that preschool teachers face in the curriculum implementation. Unpublished master thesis. Turkey: Middle East Technical University.

Fiedler, M. L. (1975). Bidirectionality of influence in classroom interaction. Journal of Educational Psychology, 67, 735-744.

Fullan, M. (2007). The new meaning of educational change. New York: Teachers College Press

Gallup, Inc. (2013). U.S. overall: Gallup student poll results, 1-6. 
Kidwell, C. F. C. (2010). The impact of student engagement on learning: The critical $10^{\text {th }}$ EPC for California. Journal of the Association of California School Administrators.

Little, A. W. (2008). 'Size matters for EFA.' CREATE Pathways to Access No 26.Consortium for Research on Educational Access, Transitions and Equity: University of Sussex.

Marks, H. M. (2000). Student engagement in instructional activity: patterns in the elementary, middle, and high school years. American Educational Research Journal, 37, 153-184.

McIntyre, L. J. (1999). The practical skeptic: Core concepts in sociology. Mountain View, CA: Mayfield Publishing.

MoE (2002). Report of the President's Committee on Review of Education Reforms in Ghana (Anamuah- Mensah Report). Accra: Ministry of Education

MoE. (2012). Preliminary education sector performance report. Accra: Ministry of Education.

MoE. (2016). Education sector performance report. Accra: Ministry of Education

MOEYS (2004). White paper on the report of the education review committee. Ghana: Ministry of education, youth and sports.

Ozder, H. (2011). Self-Efficacy Beliefs of Novice Teachers and Their Performance in the Classroom. Australian Journal of Teacher Education, 36(5).

Pianta, R. C (2007. Early childhood education in transition. In R. C. L. Snow (Eds.). School readiness and transition to kindergarten in the era of accountability (pp. 3-10). Baltimore, MD: Paul H. Brookes Publishing Co., Inc.

Stovall, I. (2003). Engagement and Online Learning. UIS Community of Practice for Learning. http://otel.uis.edu/copel/EngagementandOnlineLearning.

Student Engagement (2014, April 28). In S. Abbott (Ed.). The glossary of educational reform by Great School Partnership. Retrieved from http://edglossary.org/studentengagement.

World Bank. (1997). Staff appraisal of Republic of Kenya childhood early development project. Nairobi: World Bank Resident Mission.

Cobbold, C., \& Boateng, P. (2015). Exploring the instructional practices efficacy beliefs of kindergarten teachers in the Kumasi metropolis of Ghana. Journal of Developing Country Studies, 5(6), 174-187.

Cobbold, C., \& Boateng, P. (2016). How confident are kindergarten teachers in their ability to keep order in the classroom? A study of teacher efficacy in classroom management. Journal of Education and Practice, 7(36), 181-190.

Deci, E. L., \& Ryan, R. M. (2000). The "what" and "why" of goal pursuits: Human needs and the self-determination of behaviour. Psychological Inquiry, 11, 227-268. 
George, D., \& Mallery, P. (2003). SPSS for Windows step by step: A simple guide and reference. Boston: Allyn \& Bacon.

Gliem, J. A., \& Gliem, R. R. (2003). Calculating, interpreting, and reporting Cronbach's Alpha Reliability Coefficient for Likert Type Scales. A paper presented to Midwest Research to Practice Conference in Adult, Continuing, and Community Education.

Gravetter, F. J., \& Forzano, L. A. B. (2009). Research methods for the behavioural sciences. Belmont, CA: Wadsworth Cengage.

Kortering, L., \& Braziel, P. (2008). Engaging youth in school and learning: The emerging key to school success and completion. Psychology in the Schools, 45(5), 461465.

O’Farrell, S. L., \& Morrison, G. M. (2003). A factor analysis exploring school bonding and related constructs among upper elementary students. California School Psychologist, 8, 53-72.

Olson, A. L., \& Peterson, R. L. (2015). Student Engagement, Strategy Brief. Lincoln, NE: Student Engagement Project, University of Nebraska-Lincoln and the Nebraska Department of Education.

Skinner, E. A., \& Pitzer, J. (2012). Developmental dynamics of engagement, coping and everyday resilience. In S. Christenson, A. Reschly, \& C. Wylie (Eds.). the handbook of research on student engagement (pp. 21-45).

Tschannen-Moran, M., \& Woolfolk Hoy, A. (2001). Teacher efficacy: Capturing an elusive construct. Teaching and Teacher Education, 17, 783-805.

Tschannen-Moran, M., \& Woolfolk Hoy, A. (2002). The influence of resources and support on teachers' efficacy beliefs. Paper presented at the annual meeting of the American Educational Research Association, New Orleans.

Wang, M. T., \& Holcome, R. (2010). Adolescents' perceptions of school environment, engagement and academic achievement in middle school. American Educational Research Journal, 47, 633- 662.

Altermatt, E. R., Jovanovic, J., \& Perry, M. (1998). Bias or responsibility? Sex and achievement-level effects on teacher classroom questioning practices. Journal of Educational Psychology, 90, 510- 517.

Anderson, A. R., Christenson, S. L., Sinclair, M. F., \& Lehr, C. A. (2004). Check \& Connect: The importance of relationships for promoting engagement with school. Journal of School Psychology, 42(2), 95-113.

Appleton, J. J., Christenson, S. L., \& Rulong, M. J. (2008). Student engagement with school: Critical conceptual and methodological issues of the construct. Psychology in the Schools, 45, 369-386. 
Archambault, I., Janosz, M., Morizot, J., \& Pagani, L. (2009). Adolescent behavioural, affective, and cognitive engagement in school: Relationship to dropout. Journal of School Health, 79(9), 408-415.

Chen, P. S. D., Gonyea, R., \& Kuh, G. (2008). Learning at a distance. Journal of Online Education, 4(3).

Cohen L., Manion L., \& Morrison, K. (2007). Research methods in education. New York: Routledge.

Finn, J. D., \& Rock, D. A. (1997). Academic success among students at risk for school failure. Journal of Applied Psychology, 82, 221-234.

Fredricks, J., Blumenfeld, P., \& Paris, A. (2004). School engagement: Potential of the concept, state of the evidence. Review of Educational Research, 74, 59-109.

Kuh, G. D., Kinzie, J., Buckley, J. A., Bridges, B. K. \& Hayek, J.C. (2007). Piecing Together the Student Success Puzzle: Research, Propositions, and Recommendations. ASHE Higher Education Report, 32, 5. San Francisco: Jossey-Bass.

Ladd, G. W., Birch, S. H., \& Buhs, E. S. (1999). Children's social and scholastic lives in kindergarten: Related spheres of influence? Child Development, 70(6), 1373-1400.

Raudenbush, S., Rowen, B., \& Cheong, Y. (1992). Contextual effects on the selfperceived efficacy of high school teachers. Sociology of Education, 65, 150-167.

Tschannen-Moran, M., Woolfolk Hoy, A., \& Hoy, A. W. (1998). Teacher efficacy: Its meaning and measure. Review of Educational Research, 68, 202-248. 